\title{
КЕРУВАННЯ ПРОЦЕСОМ МАСАЖУ ПРИ КОРЕКЦІї ГОЛОВНОГО БОЛЮ ІЗ ВИКОРИСТАННЯМ БІОЛОГІЧНОГО ЗВОРОТНОГО ЗВ'ЯЗКУ
}

\author{
М. А. Лябах, Ю. П. Горго' \\ Комунальний заклад Київської обласної ради «Київська обласна клінічна лікарня» \\ Національний технічний університет України “Київський політехнічний інститут»
}

\begin{abstract}
У статті показано, що використовуючи різні фізіологічні, біофізичні, психофізіологічні та лікувальні методи, можна здійснити керівні впливи на людину, яка страждає від головного болю чи розумової дисфункції. Це відбувається шляхом гальмівних чи збуджувальних впливів на людину з метою корекції, оптимізації чи активізації їі розумової діяльності. При цьому добрим методом корекції розумових дисфункцій та головного болю $є$ використання зонально-рефлекторного масажу тригерних зон голови. Але тут існують певні шляхи та принципи коригувальних впливів на головні болі та розумові дисфункції.
\end{abstract}

Ключові слова: зонально-рефлекторний масаж, тригерні зони, біологічні зворотні зв'язки, шляхи та принципи корегуючих впливів.

\section{УПРАВЛЕНИЕ ПРОЦЕССОМ МАССАЖА ПРИ КОРРЕКЦИИ ГОЛОВНОЙ БОЛИ С ИСПОЛЬЗОВАНИЕМ БИОЛОГИЧЕСКОЙ ОБРАТНОЙ СВЯЗИ}

\author{
М. А. Лябах, Ю. П. Горго' \\ Коммунальное учреждение Киевского областного совета \\ «Киевская областная клиническая больница»
}

Национальный технический университет Украины “Киевский политехнический институт»

В статье показано, что используя разные физиологические, биофизические, психофизиологические и лечебные методы можно осуществить управляющие воздействия на человека, который ощущает головную боль или умственные дисфункции. Это происходит, если проводить тормозные или возбуждающие воздействия на человека с целью коррекции, оптимизации или активизации его умственной деятельности. Очень хорошим методом коррекции умственных дисфункций и головных болей определено использование зонально-рефлекторного массажа триггерных зон головы с использованием биологических обратных связей. При этом существуют определенные пути и принципы коррегирующих воздействий при головных болях и умственных дисфункциях.

Ключевые слова: зонально-рефлекторный массаж, тригерные зоны, биологические обратные связи, пути и принципы коррегирующих воздействий.

\section{MANAGEMENT OF MASSAGE PROCESS WITH CORRECTION OF THE HEADACHE USING BIOFEEDBACK}

\author{
M. A. Liabakh, Yu. P. Horho' \\ Communal Establishment of Kyiv Regional Council «Kyiv Regional Clinical Hospital» \\ National Technical University of Ukraine «Kyiv Polytechnic Institute»"1
}

\begin{abstract}
The article adduces the utilizing different physiological, biophysical, psychophysiological and medical methods to carry out the managing affecting man who is in head pains or mental dysfunctions. It takes a place to conduct the brake or excitant affecting man with the purpose of correction, optimization or activation of his intellection. The use of zonally-reflex massage of triggering areas of head is certain the very good method of correction of mental dysfunctions and head pains with the use of biofeedback. Thus, there are certain ways and principles of correcting influences at head pains and mental dysfunctions.
\end{abstract}

Key words: zonally-reflex massage, triggering areas, biofeedback, ways and principles of correcting influences.

(C) М. А. Лябах, Ю. П. Горго 
Вступ. У літературі представлено діагностичні прийоми, які застосовують для оцінювання ступеня прояву та походження головного болю [1]. Об'єктивне оцінювання ступеня прояву та походження головного болю потрібне, насамперед, для подальшої корекції. Використовуючи різні фізіологічні, біофізичні, психофізіологічні та лікувальні методи можна здійснити керівні впливи на людину, яка відчуває головний біль чи розумові дисфункції, гальмівну чи збуджувальну дію на людину з метою корекції, оптимізації чи активізації ії розумової діяльності $[2,3]$. Розумовими дисфункціями ми вважаємо зміни нормальної розумової діяльності та прояв неадекватних реакцій при розумових навантаженнях. Дуже добрим методом корекції розумових дисфункцій та головного болю $є$ використання зонально-рефлекторного масажу тригерних зон голови [4]. Але тут ми визначаємо певні шляхи та принципи коригуючих впливів на головний біль та розумові дисфункції, які будуть розглянуті далі.

Вплив на головний біль і розумові дисфункціїлюдини може бути здійснений двома різними шляхами. По-перше, це цілий ряд зовнішніх по відношенню до індивіда факторів, які впливають на зміни його функціональних станів та ефективність його діяльності. Сюди в повній мірі відносяться різні засоби фізичної реабілітації і перш за все - масажу. 3 другого боку, сама людина за допомогою тих чи інших прийомів фізичної реабілітації і самомасажу може активізувати свої внутрішні можливості регулювати власні функціональні стани (ФС) $[5,6]$.

Направлені зміни функціональних станів та розумових дисфункцій і головного болю людини можна здійснити шляяхом лікування, корекції, керування, допомоги $[7,8]$. Між ними є різниця. Вважаємо, що лікування - це лікування та корекція головного болю і розумових дисфункцій патологічного чи екстремального рівня до нормального (оптимального) рівня. Корекція -це зміни ФС та розумових дисфункцій людини у вигляді допомоги для здійснення необхідних реакцій припевних зовнішніх робочих, психофізіологічних чи фізичних навантаженнях. Найдієвішою єоптимальна корекція, тобто індивідуальне оптимальне погодження психофізіологічних та професійних можливостей людини з характеристиками зовнішніх подразнень. Керування ФС чи розумовою діяльністю людини - це зміни їх до певного визначеного рівня, необхідного для досліджень чи для роботи. Керування ФС не обов'язково відбувається до оптимального рівня, людині можна нормалізувати, активізувати чи гальмувати розумову діяльність, вводити в стан спокою чи в іншпий необхідний стан.
Постановка проблеми. Для коригуючих впливів можна застосувати багато різних прийомів. Нами їх класифіковано та поділено на такі групи [8]:

А. Коригуючі впливи, що змінюють ФС людини із зовнішньою допомогою. Якщо надається зовнішня допомога, то людині необхідно з нею повністю погоджуватись і повністю ії̈ усвідомлювати:

1. Лікування у випадку розвитку патологічних процесів, його виконує обов'язково кваліфікований лікар.

2. Корекційні впливи, куди належать психотерапевтичні, фізіотерапевтичні впливи, лікувальна фізкультура, масаж, гіпноз, заняття спортом тощо. Всі ці впливи застосовують для об' єктивної зміни ФС людини після роботи чи навантажень. Такі корегуючі впливи застосовуються «людиною, яка приймає рішення» (ЛПР) [9]: лікарем, реабілітологом, масажистом, дослідником, а на виробництві - членами колективу (рис. 1). При цьому необхідне виконання таких умов: об'єктивна оцінка ФС людини, людина повинна знати та довіряти ЛПР; наявність установки і мотивації людини на проведення конкретних процедур.

Розглядаючи організм людини як динамічну ланку біотехнічної системи (БТС), що пов'язана детермінованою системою із суттевим запізненням (нелінійністю), використовують передавальну функцію «поведінки» від вхідних сигналів до певних вихідних реакцій [10]. Вона припускає використання в якості вихідної подібної математичної моделі людини, що забезпечує підхід до неї як до «поведінково» детермінованої ланки БТС. Ця детермінованість забезпечується підготовкою (навчанням) людини до процедур і впливом техніко-фізіологічних зовнішнніх впливів. У режимі стеження за людиною при зміні зовнішніх впливів її передавальна функція в плані поведінки визначалась:

$$
W(p)=\frac{X_{b}(t)}{X_{a}(t)}=\frac{e^{-p \tau(\alpha, \beta)}\left[T_{1}(\alpha, \beta) p+1\right]}{P\left[T_{2}(\gamma, \beta) p+1\right]\left[T_{3}(\gamma, \beta) p+1\right]},
$$

де $X_{a}(t)$ - зміна зовнішнього впливу; $X_{b}(t)-$ реагування організму людини на зміну $X_{a}(t) ; \tau(\alpha, \beta)$ - час реакції (латентний період) на зовнішні впливи, що $€$ функцією складності поставленої задачі $\alpha$ і стану $\beta$ людини; $\alpha$-містить сукупність: закономірності форми, інтенсивності сигналу, його контрастності відносно навколишнього шуму тощо; $\beta$-відображає готовність людини до виконання задачі, ступінь підготовки, тренованості тощо; $T_{1}(\alpha, \beta)$ - постійна часу ланки, що формує «свідоме перерегулювання); $\mathrm{T}_{2}-$ залежить від $\beta$ і параметра $\gamma$, що характеризує ча- 


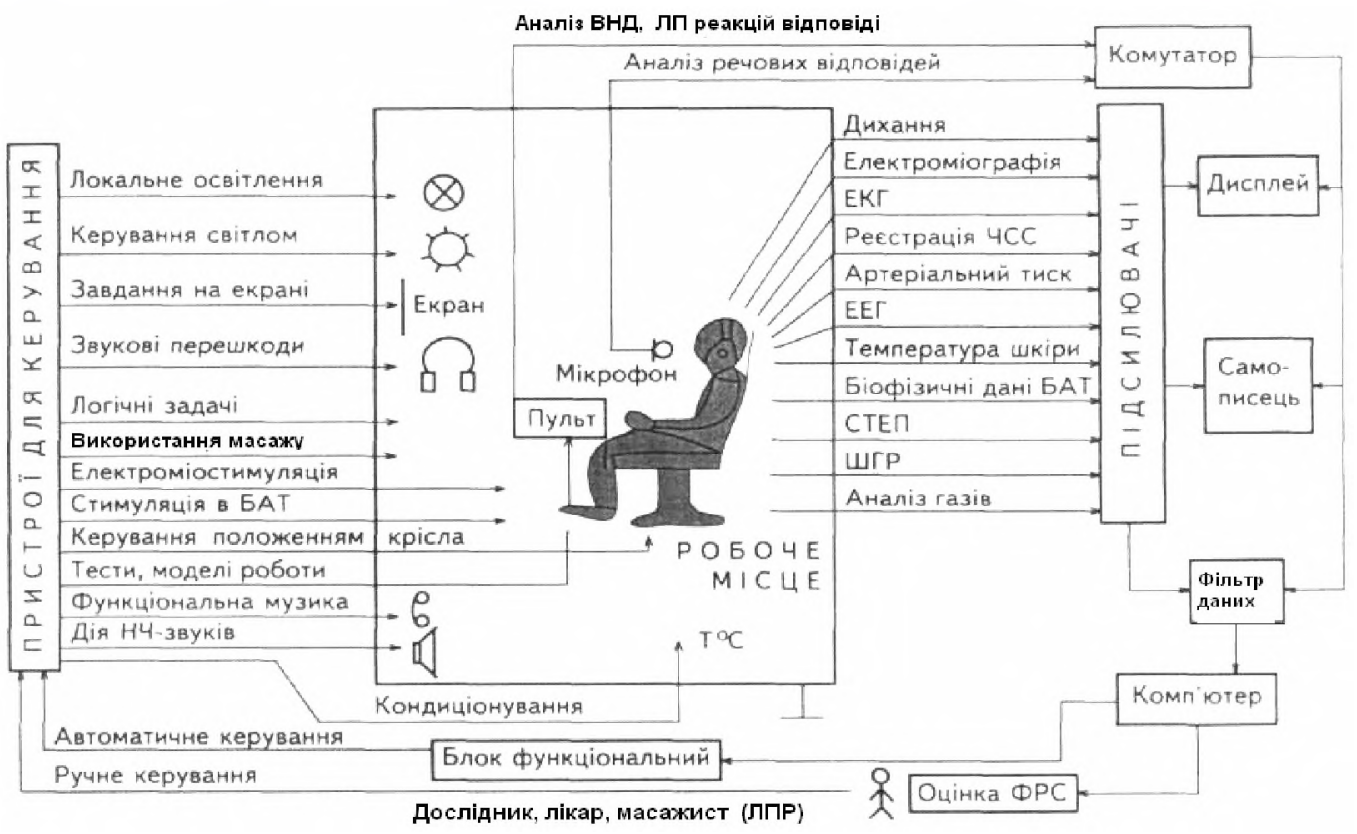

Puc. 1. Блок-схема системи оцінки та керування функціональними робочими станами (ФРС) та дисфункціями розумової діяльності людини у модельному та реальному режимах роботи, де ВНД - вища нервова діяльність; ЛП - латентні періоди; СТЕП - статичні електричні потенціали шкіри; ШІГР - шкірногальванічні рефлекси; $\mathrm{T}^{\circ} \mathrm{C}$ - температура приміщення; НЧ - низькочастотний.

сові особливості роботи людини; $\mathrm{T}_{3}(\gamma, \beta)-$ визначає його інерційність.

3. Зміна роду діяльності чи додаткове тренування робочих навичок з метою корекції професійної діяльності.

Б. Корегуючі впливи, що змінюють ФС людини самостійно. Можуть надаватися людиною самостійно, в деяких випадках навіть без усвідомлення наявності впливу:

1. Зміна самих розумових навантажень людини шляхом їх уповільнення, прискорення чи інших змін часу та інтенсивності навантаження. Такі корегуючі впливи застосовують в випадках, якщо можна це зробити без шкоди для виробничих процесів.

2. Самовпливи людини, що коригують власний ФС за необхідністю чи при суб' єктивній необхідності. Сюди належать такі способи самовпливів: аутогенне тренування, самонавіювання, самогіпноз, самомасаж, застосування фармакологічних чи стимулювальних засобів, зміна робочої пози тощо.

В реальних умовах виробництва можливе створення автоматизованих та напівавтоматизованих систем керування функціональними станами людини. При цьому треба виходити з того, що коригуючі впливи можна робити трьома шляхами:

1) Результати оцінки ФС людини за їі фізіологічними показниками пропонуються йй (рис. 1) по зворот- ному зв'язку, і вона може самостійно коректувати свою діяльність методами самовпливів.

2) Дані про оцінки ФС людини надаються також “людині, що приймає рішення" (ЛПГР) і вона може коректувати розумову діяльність людини через “блок керування" (рис.1) шляхом застосування різних підходів: самостійно, з використанням техніко-фізіологічних методів, зміною робочої ситуації тощо.

3) 3 виходу блоку “оцінки стану” через “блок керування" (рис.1) можна також здійснювати вплив на людину, яка в даному випадку розглянута як «людина-оператор» (ЛО), обминаючи ЛІГІР, але це лише при високому ступені автоматизації процесу. Найчастіше зворотні зв'язки замикаються через ЈIГІР, в якості якої виступає лікар чи реабілітолог з великими знаннями чи досвідом. ЈIГР, як правило, знаходиться в менш складних умовах, ніж пацієнт, і виконує функції судді. Як показує практика, присутність ЛІГІР для корекції ФС людини при складних розумових дисфункціях обов'язкова.

Метод біологічного зворотного зв'язку. ЯК відомо [10-12], прийоми біологічного зворотного зв'язку (Б33) базуються на ресстрації фізіологічних параметрів, зміни яких можна подавати людині за допомогою сенсорних відчуттів. Ця об'єктивна інформація дозволяє людині оцінювати ступінь успішності застосованих впливів, $є$ зовнішнім орієнтиром для 
зіставлення з власними підсвідомими відчуттями, а також знімає певну невизначеність результату впливу. Ми використали ці прийоми для біологічних зворотних зв'язків при застосуванні відомих методів сегментарно-рефлекторного і точкового масажу [4, 5] на тригерні зони голови [13]. Ми пропонуємо застосовувати методи об' єктивної оцінки дії масажу за змінами температури та електричних потенціалів в активних зонах шкіри (АЗШ) голови $[11,13]$. На цих принципах була розроблена система із біологічним зворотним зв' язком, що дозволяє людині по зоровому чи звуковому каналу оцінити ступінь збудження чи гальмування своєї нервової системи, у тому числі і дію масажу чи самомасажу [13] (рис. 2). Застосована система вимірює зміни температури та статичних електричних потенціалів (СТЕП) шкіри голови в активних зонах шкіри (АЗШ), частоти серцевих скорочень та опору шкіри при масажі, від змін цих значень спрацьовують порогові пристрої [12, 13], що викликає зміну тону звуку у навушниках чи світлової сигналізації (рис. 2, 3).

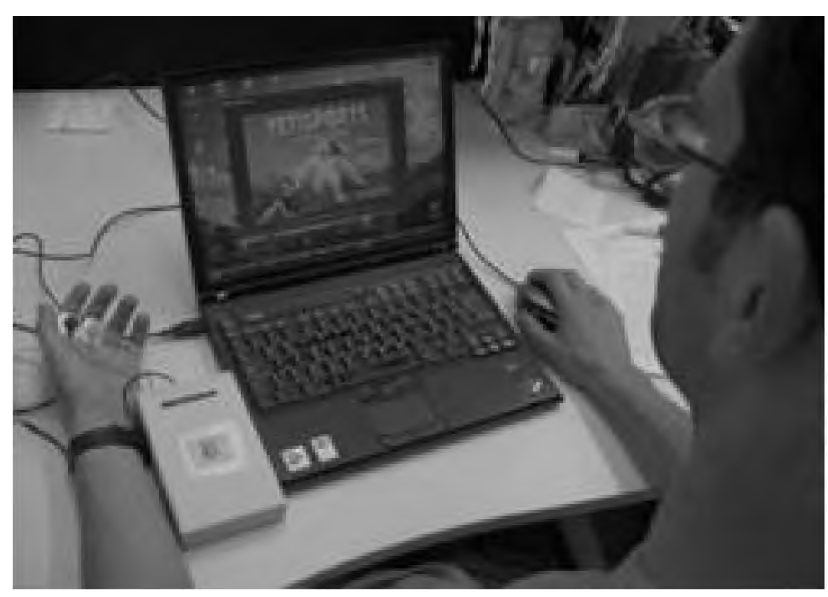

Puc. 2. Вимірювальний блок та виносний пульт системи для біологічного зворотного зв'язку при дії різних корегуючих процедур при розумових дисфункціях.

Дуже важливим фактором цього методу Б33 є активна позиція самого суб' єкта впливу, яка підвищує ефективність застосовуваних засобів корекції ФС. В цій системі оцінка ФС проводилась по параметрах температури та СТЕП в АЗІІ голови, які і $є$ тригерними зонами [13], реєстрації електричного опору, а також значень кардіоінтервалів $[12,14]$. Реєстрація параметрів температури шкіри та СТЕП провадилась по 2-х каналах для того, щоб можна було реєструвати їх в симетричних органоспецифічних зонах шाкіри та в суміжній зоні (рис. 3). Збілышення значень амплітуди та асиметрії СТЕП в АЗІІ голови свідчили про збудження нервової системи досліджуваного при масажі, а зменшення цих біофізичних характеристик - про гальмування. По звуковому чи світловому каналах досліджуваний сам оцінював ступінь збудження своєї нервової системи. Виконуючи самовпливи на організм, наприклад, самомасаж, досягають того, щоб світився індикатор певного кольору чи звучав звук певного тону.

Блок реєстрації загального опору шкіри також призначений для оцінки ступеня збудженості нервової системи. За відомими даними [10, 14], підвищення опору шкіри відбувається при гальмуванні нервовопсихічної діяльності людини, азниження опору - при підвищенні нервово-психічного збудження. Пороговий пристрій керування звукогенератором настроювався за індивідуальними значеннями електричного опору досліджуваного. При цьому чим менший опір тіла, тим вищий тон подається в навушники. У цій системі діапазон реєстрації електричного опору, при струмі в 50 мкА, був не менше 10-1000 кОм 3 точністю вимірювань 1 кОм. При використанні цього параметра вводились регулятори: установки “О”, калібровки балансу (рис. 3).

Оскільки опір шкіри тіла людини змінюеться під час змін нервово-психічного напруження, ця система дає сигнал для розслаблення на самому ранньому етапі наростання напруги. Ми використовували систему для зниження інтенсивності нападів мігрені. Звуковий сигнал регулювали так, щоб бажана зміна функції (гальмування, збудження) - приводила до зниження звуку. В іншому випадку посилення звуку при впливах масажу стане заважати довільному контролю, як додатковий стрес-фактор.

Лікувальне застосування методу Б33 передбачає, що інформація про роботу органів і систем отримується за допомогою реєструючої апаратури, підсилюється і подається людині у вигляді звукового або візуального сигналу. Таким чином аферентна інформація йде по штучних каналах, що утворюють нову «Петлю) зворотного зв'язку [15]. 3 клінічної точки зору, за допомогою БЗ3 людина навчається довільно регулювати деякі функції, наприклад частоту серцевих скорочень і дихання, напругу скелетної мускулатури, тонус і кровонаповнення судин і т.д. S. Diamond [16] описав програму лікування при допомозі Б33: спочатку хворому пояснюють роль окремих етапів лікування, знайомлять із обстановкою приміщення і реєструючою апаратурою. У довірливій бесіді домагаються позитивної установки хворого на це лікування. На першому етапі (4 тижні) хворі проходять 


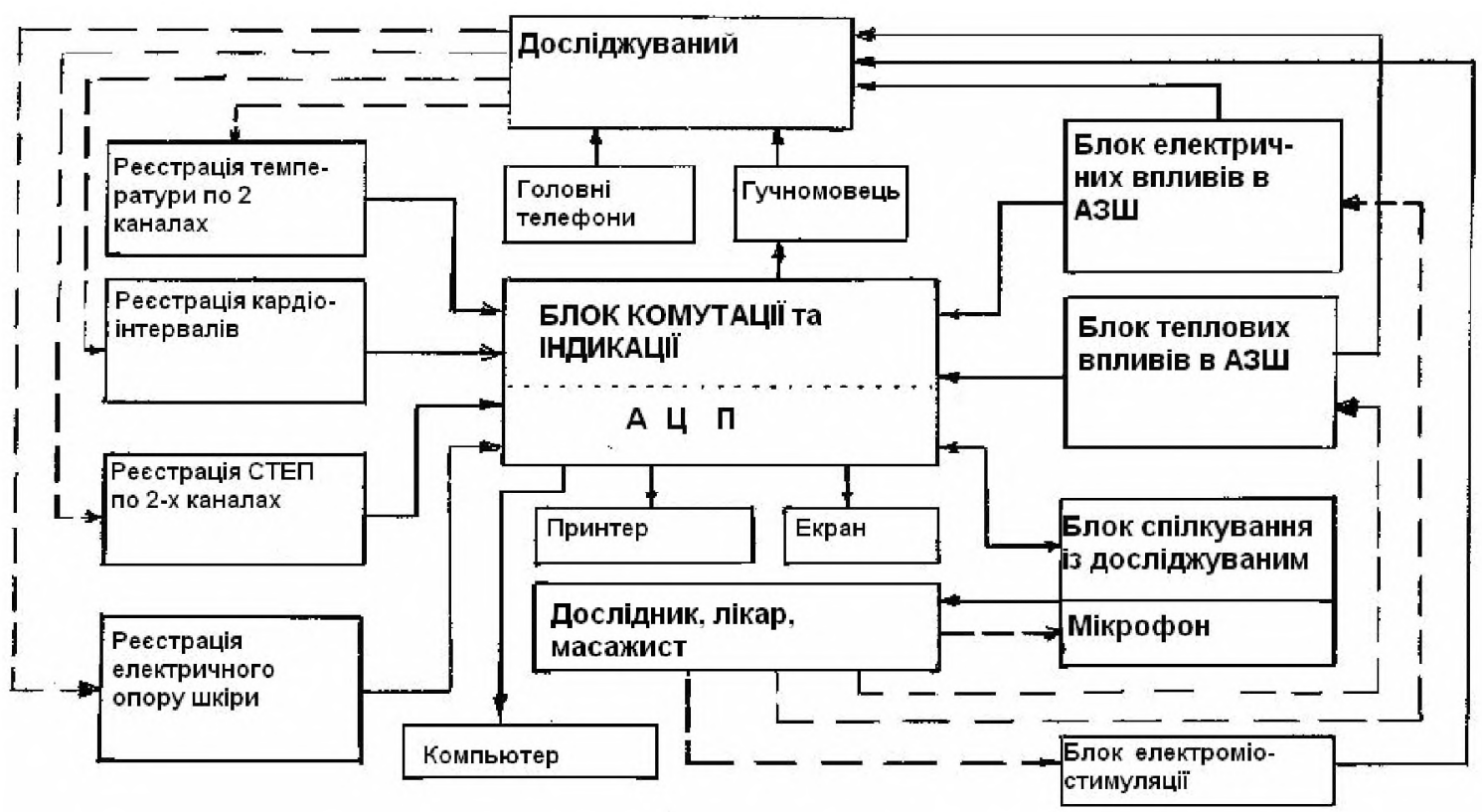

Puc. 3. Блок-схема системи біологічного зворотного зв'язку для оцінки та корекції функціональних станів людини. Переривчастими лініями вказані зв'язки, якими керує дослідник, лікар чи масажист.

курс аутогенного тренування 2-3 рази на тиждень у поліклініці і щодня повторюють заняття 1-2 рази самостійно в домашніх умовах. Після цього приступають до сеансів за методом БЗ3. Як і аутогенне тренування, їх проводять у комфортній обстановці, що сприяє розслабленню і заспокоєнню. Звуковий сигнал регулюється так, щоб бажана зміна функції збільшення кровонаповнення і температури кисті, зменшення пульсації скроневої артерії або зменшення напруги м'язів - приводило до зниження звуку. У ході заняття хворий навчається довільно зменшувати пульсацію скроневої артерії, а пацієнти з болем м'язової напруги - розслаблювати м'язи.

Інтимні механізми лікувальної дії БЗЗ не визначені, але вважається, що воно обумовлене зниженням симпатичної активації [16]. У багатьох роботах підкреслюється більша ефективність Б33, порівняно із психотерапевтичними методами і плацебо, а також залежність ефекту від позитивної психологічної установки на лікування. Існують переваги використання методу Б3З: він може зменшпити кількість прийнятих ліків або взагалі виключити необхідність їх застосування. Він може бути ефективним у деяких ситуаціях, коли ліки безсилі. Він мобілізує пацієнта, вчить керувати своїм організмом. Він знижує витрати на лікарські препарати і зменшує ймовірність появи побічних ефектів від медикаментозної терапії [16]. При використанні приладів БЗ3 самостійно необхідно консультуватися 3 лікарем, так як використання цього підходу може впливати на дію деяких ліків [3,5].

Результати та їх обговорення. Після дії зонального масажу при головних болях тригерних зон голови із використанням та без використання БЗ3 вимірювались значення вегетативних показників досліджуваних (табл. 1).

Таблиця 1. Зміни вегетативних показників при масажі тригерних лобних зон із використанням та без використання Б33 $(\mathrm{n}=60)$

\begin{tabular}{|c|c|c|c|c|}
\hline \multirow{2}{*}{ Фізіологічні показники } & \multicolumn{2}{|c|}{ Артер. тиск (мм рт. ст.) } & \multirow{2}{*}{$\begin{array}{c}\text { ЧСС, } \\
\text { (уд/хв) }\end{array}$} & \multirow{2}{*}{ t, ${ }^{\circ} \mathrm{C}$} \\
\cline { 2 - 3 } & систолічний & діастолічний & \\
\hline До досліджень & $123,8 \pm 2,4$ & $80,7 \pm 1,5$ & $76,8 \pm 2,8$ & $36,6 \pm 0,04$ \\
\hline Після масажу без Б33 & $129,5 \pm 1,4$ & $86,0 \pm 1,2$ & $82,1 \pm 2,7$ & $36,4 \pm 0,04$ \\
\hline Після масажу із Б33 & $117,4 \pm 2,4$ & $75,6 \pm 2,1$ & $70,5 \pm 1,2$ & $36,7 \pm 0,03$ \\
\hline $\mathrm{p}$ & $\mathrm{p}<0,05$ & $\mathrm{p}<0,05$ & $\mathrm{p}<0,05$ & $\mathrm{p}>0,05$ \\
\hline
\end{tabular}


3 таблиці 1 видно, що після масажу із Б33 спостерігалось достовірне зменшення величини артеріального тиску, частоти серцевих скорочень, а значення температури шкіри АЗШ голови достовірно не змінювалось, а після масажу без Б33 спостерігалось достовірне збілышення цих величин. Це вказує на нормалізуючий вплив при використанні масажу із Б33.
Нами також досліджено вплив масажу тригерних зон голови із використанням Б33 при розумових дисфункціях. Ввизначались такі психофізіологічні показники, як функціональна рухливість нервових процесів (ФРНП), показник успішності роботи (ПУР), час реакції (ЛП) на світловий та звуковий подразники (табл. 2).

Таблиця 2. Зміни психофізіологічних показників під впливом масажу із використанням Б33 $(\mathrm{n}=48)$

\begin{tabular}{|c|c|c|c|c|c|}
\hline $\begin{array}{c}\text { Фізіологічні } \\
\text { показники }\end{array}$ & $\begin{array}{c}\text { ЛП } \\
\text { світло, (мс) }\end{array}$ & $\begin{array}{c}\text { ЛП } \\
\text { звук, (мс) }\end{array}$ & $\begin{array}{c}\text { ФРНП, } \\
(\text { мс })\end{array}$ & \multicolumn{2}{|c|}{ ПУР } \\
\hline До масажу & $361 \pm 7,6$ & $469 \pm 8,1$ & $429 \pm 10,4$ & $362 \pm 10,4$ & $347 \pm 15,6$ \\
\hline Після масажу & $330,6 \pm 8,7$ & $437 \pm 9,4$ & $392 \pm 11,8$ & $465 \pm 14,7$ & $351 \pm 12,8$ \\
\hline $\mathrm{p}$ & $\mathrm{p}<0,05$ & $\mathrm{p}<0,05$ & $\mathrm{p}<0,05$ & $\mathrm{p}<0,05$ & $\mathrm{p}<0,05$ \\
\hline
\end{tabular}

Із таблиці 2 бачимо, що після проведення масажних процедур лобних зон достовірно зростає значення ПУР у 70 \% досліджуваних, а в 30 \% досліджуваних ПУР майже не змінюеться. Також спостерігалось збільшення ФРНП та достовірне зменшення після масажу середніх величин часу реакції на світловий та звуковий сигнали. Це вказує на покращання значень психофізіологічних показників, які значно знижуються при розумових дисфункціях, при застосуванні масажу зон голови із використанням Б33 (табл. 2).

Використання біологічних зворотних зв'язків при лікуванні мігрені проводилось у хворих в 1-й обласній клінічній лікарні м. Києва. За нашими даними, що узагальнюють 4-річний досвід лікування головного болю із використанням масажу лобних АЗШ із зворотними зв' язками, при лікуванні 233 хворих у віці від 16 до 72 років суттєве поліпшення настало в $79 \%$ випадків. Ефективність лікування була значно вищою у молодих пацієнтів. Тільки $61 \%$ хворих зберегли здатність ефективно користуватися отриманими навичками довільного контролю головного болю протягом наступних 4 років. При лікуванні мігрені ми рекомендували наступну програму. Тривалість масажу лобних АЗШ від 15 до 60 хв залежно від успіхів пацієнта, їх повторюють 3 рази на тиждень протягом 4 тижнів. 3 початку лікування хворий обов' язково веде щоденник, в якому відзначає частоту й інтенсивність болю та ефективність спроб зупиняти біль із використанням отриманих навиків. Јнтенсивний стаціонарний курс Б33 триває 2 тижні по 2-3 сеанси щодня. Хронічний головний біль при межових станах теж можна лікувати використанням масажу в АЗШ із методом Б33.

Висновок. Головний біль при різних межових станах теж можна лікувати з використанням методу Б33. Нами застосовано метод Б33 із СТЕП контролем i температурним контролем, проведено психологічне тестування хворих для визначення соматизації, порушення міжособистісних відносин, тривоги і депресіі, обсесивно-фобічних симптомів. Відзначено, що поряд із ослабленням головного болю зменшувалася й виразність супровідних невротичних симптомів. Ці результати не збігаються із твердженням психологів про те, що у хворих на невроз зменшення виразності провідного симптому (у цьому випадку головного болю) приводить до більшої вираженості інших або появи нових симптомів. Позитивний ефект лікування методом Б33 можна отримати тоді, коли вдається встановити добрий контакт із хворим; хворий за своїми особистісними якостями, самодисципліною, здатністю трансформувати ідеї про нові методи лікування у власні установки, підходить для лікування цим методом; анамнестичні дані свідчать про позитивну реакцію хворого на вплив і самонавіювання і тим більше на попередній досвід лікування методом Б33. Перешкодою до лікування методом Б33 може бути невротична депресія з установками хворого, а також лікарська залежність, що сформувалася при багаторічному лікуванні. Велике значення має i здатність лікаря вступати в неформальний довірчий контакт із пацієнтами.

подред. Н. Н. Яхно, Д. Р. Штульмана.- М. : Медицина, 2001.

-C. $418-432$.

\section{Література}

1. Вейн А. М. Неврологические аспекты невротических расстройств // Болезни нервной системы / Дюкова Г. М; 
2. Колосова О. А. Классификация головной боли / Осипова В. В.// Неврология и психиатрия - 1996. - №3.-С. 8-11. 3. Болевые синдромы в неврологической практике / под ред. А. М. Вейна. - М. : Медпресс, 1999. - 365 с.

4. Ісаєв Ю. О. Сегментарно-рефлекторний і точковий масаж у клінічній практищі / Ю. О. ІсаєВ. - К. : 'Здоров'я, 1993. $-320 \mathrm{c}$.

5. Васичкин В. И. Справочник по массажу / В. И. Васичкин. - СПб. : Гиппократ, 1992.-354 с.

6. Горго Ю. П. Фізіологічна кібернетика та інформатика людини / Ю. П. Горго.-К. : Поліграфсервіс, 2010.-110 с. 7. Горго Ю. П. Информационный подход к оценке изменений физиологических характеристик оператора при разных режимах его работы / Ю. П. Горго // Физиология человека. - 1986.- Т. 12, № 2.-С. 161-168.

8. Горго Ю. П. Алгоритм выбора методов оценки и управления функциональными рабочими состояниями / Ю. П. Горго // Кибернетика и вычислительная техника.1994.- Вып. 99.-- С. 21-27.

9. Горго Ю. П. Информационная оценка физиологических сигналов человека при изменении его психоэмоциональных состояний / Ю. П. Горго // Педагогіка, психологія та медико-біологічні проблеми фізичного виховання та спорту. -2007 . - № 6. - С. $82-86$.
10. Попадюхха А. А. Інформаційні технології та біофізичні оцінки діяльності операторів в біотехнічних системах / А. А. Попадюха, Ю. П. Горго. - К. : ПВП «Задруга», 2008.$199 \mathrm{c}$.

11. Горго Ю. П. Психофізіологія (прикладні аспекти) / Ю. П. Горго. - К. : МАУП, 1999. - 123 с.

12. Горго Ю. П. Диагностирование состояний человека по кожноэлектрическим процессам / Ю. П. Горго // Нейробионика и моделирование биосистем. - 1980. - С. 64-78.

13. Лябах М. А. Особенности проведения зонально-локального и сегментарного массажа триггерных зон у людей разного возраста / М. А. Лябах, Ю. П. Горго // Интегративная медицина : тез. и докл. межд. конф., 2011, К. - С. 9596. 14. Горго Ю. П. Оцінка та керування функціональними робочими станами людини : навчальний посібник / Горго Ю. П., Маліков М. В., Богдановська Н. В. - Запоріжжя : ЗНУ, 2006. $-135 \mathrm{c}$.

15. Лябах М. А. Використання масажу для корекції функціональних станів лодини при розумових навантаженнях / М. А. Лябах, Ю. П. Горго // Семейная медицина. - 2014. №2 (52). - C. 37-39.

16. Лябах М. А. Особливості теорії і практики використання зонально-рефлекторного масажу / М. А. Лябах, Ю. П. Горго // Проблеми екологічної та медичної генетики і клінічної імунології. - 2014. - № 3. - С. 7483. 